\title{
Interferon $\gamma$ Induces Retrograde Dendritic Retraction and Inhibits Synapse Formation
}

\author{
In-Jung Kim, ${ }^{1}$ Hiroko Nagasawa Beck, ${ }^{2}$ Pamela J. Lein, ${ }^{2}$ and Dennis Higgins ${ }^{1}$ \\ ${ }^{1}$ Department of Pharmacology and Toxicology, State University of New York, Buffalo, New York 14214, and ${ }^{2}$ Department \\ of Environmental Health Sciences, Bloomberg School of Public Health, Johns Hopkins University, Baltimore, Maryland \\ 21205
}

The expression of interferon $\gamma(\mathrm{IFN} \gamma)$ increases after neural injury, and it is sustained in chronic inflammatory conditions such as multiple sclerosis and infection with human immunodeficiency virus. To understand how exposure to this proinflammatory cytokine might affect neural function, we examined its effects on cultures of neurons derived from the central and peripheral nervous systems. IFN $\gamma$ inhibits initial dendritic outgrowth in cultures of embryonic rat sympathetic and hippocampal neurons, and this inhibitory effect on process growth is associated with a decrease in the rate of synapse formation. In addition, in older cultures of sympathetic neurons, IFN $\gamma$ also selectively induces retraction of existing dendrites, ultimately leading to an $88 \%$ decrease in the size of the arbor. Dendritic retraction induced by IFN $\gamma$ represents a specific cellular response because it occurs without affecting axonal outgrowth or cell survival, and it is not observed with tumor necrosis factor $\alpha$ or other inflammatory cytokines. IFN $\gamma$-induced dendritic retraction is associated with the phosphorylation and nuclear translocation of signal transducer and activator of transcription 1 (STAT1), and expression of a dominant-negative STAT1 construct attenuates the inhibitory effect of IFN $\gamma$. Moreover, retrograde dendritic retraction is observed when distal axons are selectively exposed to IFN $\gamma$. These data imply that IFN $\gamma$-mediated STAT1 activation induces both dendritic atrophy and synaptic loss and that this occurs both at the sites of IFN $\gamma$ release and at remote loci. Regressive actions of IFN $\gamma$ on dendrites may contribute to the neuropathology of inflammatory diseases.

Key words: interferon $\gamma$; bone morphogenetic protein-7; dendrites; sympathetic neurons; hippocampal neurons; STAT1; retrograde transport
Interferon $\gamma(\mathrm{IFN} \gamma)$ is a proinflammatory cytokine that potently stimulates cell-mediated immunity (Farrar and Schreiber, 1993; Bach et al., 1997; Boehm et al., 1997). IFN $\gamma$ is made primarily by T-lymphocytes and natural killer cells; because the entry of these cells into the CNS is minimal under normal circumstances, IFN $\gamma$ is usually not detectable in the brain (Traugott and Lebon, 1988; Fabry et al., 1994). However, expression of IFN $\gamma$ rises rapidly in acute inflammatory reactions caused by trauma (Lau and $\mathrm{Yu}$, 2001), ischemia (Li et al., 2001), or viral infection (Binder and Griffin, 2001), and elevated expression persists in chronic inflammatory diseases such as multiple sclerosis (MS) (Panitch, 1992; Popko et al., 1997) and in chronic viral infection such as that produced by human immunodeficiency virus (HIV) (Fuchs et al., 1991; Fan et al., 1993). Levels of IFN $\gamma$ also are increased in murine trisomy 16, which is considered a model for Down's syndrome (Torre et al., 1995; Hallam et al., 2000). Overexpression of IFN $\gamma$ causes abnormal cerebellar and hippocampal development in transgenic mice (Corbin et al., 1996; LaFerla et al., 2000), and administration of IFN $\gamma$ to MS patients aggravates the disease (Panitch et al., 1987). Thus there is reason to suspect that the elevated levels of IFN $\gamma$ that are associated with inflammatory

\footnotetext{
Received Dec. 3, 2001; revised March 14, 2002; accepted March 18, 2002.

This study was supported by National Science Foundation Grant IBN 01-21210 and a Johns Hopkins University Bloomberg School of Public Health Faculty Innovation Award (P.L.). We thank Dr. Toshio Hirano and Dr. Katsuhiko Ishihara for kindly providing plasmids carrying wild-type and mutant STAT1 and STAT3 genes. The antibody to SV-2 was obtained from the Developmental Studies Hybridoma Bank at University of Iowa (Department of Biological Sciences, Iowa City, IA).

Correspondence should be addressed to Dr. In-Jung Kim, Department of Pharmacology and Toxicology, State University of New York at Buffalo, 102 Farber Hall, 3435 Main Street, Buffalo, NY 14214. E-mail: ikim@acsu.buffalo.edu.

Copyright (C) 2002 Society for Neuroscience $0270-6474 / 02 / 224530-10 \$ 15.00 / 0$
}

neural conditions may contribute to their pathology. However, evaluation of this hypothesis is impeded by a lack of knowledge of the direct effects of IFN $\gamma$ on neurons, and, in fact, previous studies have noted primarily beneficial effects of IFN $\gamma$ on the survival (Chang et al., 1990), growth (Erkman et al., 1989), and differentiation of isolated neurons (Barish et al., 1991; Jonakait et al., 1994).

Dendrites are the primary site of synapse formation in the nervous system (Purves, 1988), and dendritic atrophy has been observed in degenerative conditions such as Alzheimer's disease (Flood and Coleman, 1990) and Parkinson's disease (Patt et al., 1991), in Down's syndrome (Takashima et al., 1989), in chronic viral infections (Masliah et al., 1997; Li et al., 1999), and as part of the reaction to acute traumatic injury (Sumner and Watson, 1971; Yawo, 1987). It is, therefore, important to characterize molecules that cause regression of these processes. Previous studies have shown that leukemia inhibitory factor (LIF), ciliary neurotropic factor, and other members of the interleukin-6 (IL-6) cytokine family induce dendritic retraction in cultured sympathetic neurons (Guo et al., 1999) and that overexpression of LIF causes dendritic atrophy in Purkinje cells (Morikawa et al., 2000). In this study we consider the possibility that IFN $\gamma$ shares with IL-6-related cytokines the ability to interfere with the growth of dendritic processes. In addition, we have compared the signal transduction pathways involved in this action.

Our data indicate that IFN $\gamma$ adversely affects dendritic maturation and synapse formation and that it acts by a pathway distinct from that used by members of the IL-6 family, suggesting possible synergistic interaction during inflammation. Moreover, we have found that the regressive signals generated by $\operatorname{IFN} \gamma$ can be 
retrogradely transported from distal axons to neural somata. This retrograde dystrophic interaction represents a novel method for conveying information about local injury or inflammation to distant brain loci.

\section{MATERIALS AND METHODS}

Materials. Recombinant rat IFN $\gamma$, interleukin $1-\beta$ (IL-1 $\beta$ ), and human tumor necrosis factor $\alpha$ (TNF $\alpha$ ) were purchased from PeproTech (Rocky Hill, NJ). Rat IFN $\beta$ was obtained from PBL Biomedical Laboratory (New Brunswick, NJ). Recombinant human bone morphogenetic protein-2 (BMP-2), BMP-6, and BMP-7 were generously provided by Curis (Cambridge, MA).

Cell culture. Superior cervical ganglia dissected from perinatal [embryonic day 21 (E21) or postnatal day 1-2 (P1-2)] Holtzman rats (Harlan Sprague Dawley, Rockford, IL) were dissociated after treatment with trypsin $(2.5 \mathrm{mg} / \mathrm{ml})$ and collagenase $(1 \mathrm{mg} / \mathrm{ml})$ for $40 \mathrm{~min}$. Cells were plated onto poly-D-lysine-coated $(100 \mu \mathrm{g} / \mathrm{ml})$ coverslips or compartmented chambers (see below) and maintained in serum-free medium containing $\beta$-nerve growth factor (NGF; $100 \mathrm{ng} / \mathrm{ml}$ ) (Higgins et al., 1991). Then $1-2$ d later, cytosine- $\beta$-D-arabinofuranoside $(1 \mu \mathrm{m})$ was added in the media for $2 \mathrm{~d}$ to kill non-neuronal cells. Subsequently, the cultures were allowed to recover for $1 \mathrm{~d}$ and experimental treatments were begun on the sixth or seventh day in vitro.

Embryonic hippocampal neurons (E18) were isolated by the method of Goslin et al. (1998) with the modifications of Bading and Greenberg (1991). Briefly, hippocampi were dissociated by treatment with trypsin (2 $\mathrm{mg} / \mathrm{ml})$ and deoxyribonuclease $(0.6 \mathrm{mg} / \mathrm{ml})$ for $2 \mathrm{~min}$ and then exposed to soybean trypsin inhibitor $(1 \mathrm{mg} / \mathrm{ml})$ for $10 \mathrm{~min}$. Cells were plated onto poly-D-lysine $(100 \mu \mathrm{g} / \mathrm{ml})$ and laminin $(7 \mu \mathrm{g} / \mathrm{ml})$ and maintained in Neurobasal medium with B27 supplements (Invitrogen, San Diego, CA) (Brewer et al., 1993).

Compartmented cultures. Compartmented cultures (Campenot chambers) were set up as described by Senger and Campenot (1997). Briefly, $35 \mathrm{~mm}$ dishes were precoated with a layer of ammoniated rat tail collagen, followed by a layer of air-dried rat tail collagen supplemented with laminin $(10 \mu \mathrm{g} / \mathrm{ml})$. Three-compartmented Teflon dividers (Camp 10, Tyler Research Instruments, Edmonton, Alberta, Canada) were seated on top of parallel tracks scratched in the collagen substrate with a pin rake (Tyler Research Instruments) and secured in place with silicone vacuum grease (Dow Corning, Huntington Beach, CA.). Integrity of the grease seals was assessed by placing culture medium into the side chambers only and incubating the chambers overnight in a $37^{\circ} \mathrm{C}$ incubator. Cells were plated only into chambers that did not leak. Medium was removed from side compartments, and dissociated cells were plated in the center compartment in serum-free culture medium containing $100 \mathrm{ng} / \mathrm{ml}$ NGF. The next day the integrity of the seals between the compartments was reconfirmed by checking for leakage from the center into side compartments. Culture medium was then added to the side compartments of those cultures exhibiting intact seals between compartments, and cytosine- $\beta$-D-arabinof uranoside $(1 \mu \mathrm{m})$ was added to the medium in the center compartment to eliminate non-neuronal cells. After axons had extended through the grease seals into the side compartments (5-7 d after plating), NGF was withdrawn from the center compartment but was maintained in the side compartment to encourage growth of neurites into the side compartments and to eliminate neurons that had failed to extend axons into side compartments. BMP-7 (10 $\mathrm{ng} / \mathrm{ml}$ ) was added to medium in the center compartment when extensive axonal growth was evident in side compartments (within 10-12 d after plating); $4 \mathrm{~d}$ later, IFN $\gamma$ (10 or $50 \mathrm{ng} / \mathrm{ml}$ ) was added to medium in the right side compartment of a subset of cultures.

Morphological analyses. Cellular morphology was analyzed using previously described immunocytochemical methods (Lein et al., 1995). Briefly, cells were fixed with $4 \%$ paraformaldehyde $\left(15 \mathrm{~min}\right.$ at $\left.20^{\circ} \mathrm{C}\right)$ and permeabilized with $0.1 \%$ Triton X-100 for 3 min. Cells were reacted with monoclonal antibodies $(\mathrm{mAb})$ that recognize axons or dendrites and then with rhodamine-conjugated secondary antisera (Roche Diagnosis, Indianapolis, IN). Monoclonal antibodies to microtubule-associated protein-2 (MAP-2, SMI-52; Sternberger Immunocytochemicals, Baltimore, $\mathrm{MD}$ ) or to nonphosphorylated forms of $\mathrm{H}$ and $\mathrm{M}$ neurofilament subunits (SMI-32; Sternberger Immunocytochemicals) were used to visualize dendrites. Previous studies have shown that immunostaining with these antibodies reveals the entire dendritic arbor (Lein et al., 1995; Bruckenstein and Higgins, 1988b). Total dendritic length was measured with SPOT software (Diagnostic Instruments, Sterling Heights, MI). A
$\mathrm{mAb}$ to phosphorylated forms of the $\mathrm{H}$ and $\mathrm{M}$ neurofilament subunits (SMI-31; Sternberger Immunocytochemicals) was used to identify the axons of sympathetic neurons (Osterhout et al., 1992; Bruckenstein and Higgins, 1988a).

To examine synapse formation, hippocampal neurons were plated at high density $\left(\sim 16,000 / \mathrm{cm}^{2}\right)$ to increase the frequency of cellular contacts (Fletcher et al., 1994). After $5 \mathrm{~d}$ of treatment with IFN $\gamma(30 \mathrm{ng} / \mathrm{ml})$, the synaptic specializations that formed along dendrites were visualized by double-labeling the cultures with rabbit anti-MAP-2 IgG (a gift from Dr. Craig Garner, University of Alabama at Birmingham, Birmingham, AL) and mAb to synaptic vesicle protein-2 (SV-2; Buckley and Kelly, 1985) and then with rhodamine-conjugated antibody to rabbit IgG (Roche Diagnosis) and fluorescein-conjugated antibody to mouse IgG (Roche Diagnosis).

Cultures were also immunostained with rabbit $\operatorname{IgG}$ that specifically recognizes a phosphorylated form (Tyr 701) of signal transducer and activator of transcription 1 (STAT1; New England Biolabs, Beverly, MA). Fixation and permeabilization were performed according to the manufacturer's protocol.

Each experiment was performed at least three times, and data in the text and in figures are presented as the mean \pm SEM. Statistical significance was assessed with a one-way ANOVA, followed by Tukey's post hoc test.

Western blotting. Cultures were solubilized in lysis buffer containing 50 mm Tris-HCl, pH 7.4, 1 mm EDTA, 0.1\% SDS, and 2.0\% $\beta$-mercaptoethanol. After centrif ugation at $15,000 \times g$, the protein concentration was determined with the Bio-Rad protein assay (Hercules, CA). Proteins (10 $\mu \mathrm{g} /$ lane) were separated by SDS-PAGE (7.5\%) and then transferred to nitrocellulose membrane where they were probed with $\mathrm{mAb}$ to tau (Tau-2; Sigma, St. Louis, MO) or a rabbit anti-actin IgG fraction (a gift from Dr. John Kolega, State University of New York, Buffalo, NY). Next the membrane was reacted with an appropriate horseradish peroxidaseconjugated secondary antibody (Amersham, Piscataway, NJ), and bands were visualized with enhanced chemiluminescent reagent (Amersham).

Transfection. Cells were cotransfected with a plasmid coding the enhanced green fluorescent protein (pEGFP-N2, Clontech, Palo Alto, CA) and the expression vector pCAGGS containing HA-STAT1WT (hemagglutinin-tagged wild-type STAT1 gene), HA-STAT3WT, HA-STAT1F (Phe substitution for Tyr701), or HA-STAT3F (Phe substitution for Tyr 705) (Nakajima et al., 1996). Plasmids containing STAT1 and STAT3 were a generous gift from Dr. Toshio Hirano (Osaka University Medical School, Osaka, Japan). Transfection was performed using Lipofectamine 2000 (Invitrogen) according to the manufacturer's protocol. Briefly, cells were treated with $200 \mu \mathrm{l}$ of DMEM containing $1 \mu \mathrm{g}$ of DNA and $4 \mu \mathrm{g}$ of Lipofectamine. After incubation for $6 \mathrm{hr}$ cells were washed and allowed to recover for $48 \mathrm{hr}$ before experimental treatments were begun.

\section{RESULTS}

\section{IFN $\gamma$ inhibits initial dendritic outgrowth induced by BMP-7 in sympathetic neurons}

Embryonic rat sympathetic neurons extend only axons (Fig. 1) when grown in serum-free medium in the absence of nonneuronal cells (Bruckenstein and Higgins, 1988a). In contrast, exposure to BMP-7, which is produced by glial cells within sympathetic ganglia (H. Beck and P. Lein, unpublished observation), causes them to also form dendrites (Fig. 1). With moderate doses $(5 \mathrm{ng} / \mathrm{ml})$ of BMP-7, neurons typically extend two to three dendrites within the first week of treatment (Fig. 2). With maximally effective doses $(\geq 50 \mathrm{ng} / \mathrm{ml})$ there is a greater increase in both the number of dendrites (Fig. 3) and total process length, and the neurons eventually form an arbor that is equivalent in size to that observed in vivo (Lein et al., 1995).

IFN $\gamma$ did not affect the morphological development of sympathetic neurons grown under control conditions (Fig. 1). However, it profoundly depressed the initial dendritic outgrowth that occurs in the presence of BMP-7 (Fig. 1). In cultures that were treated with a maximally effective dose of BMP-7 $(50 \mathrm{ng} / \mathrm{ml})$, there was a $53 \%$ decrease in the number of dendrites per cell in the presence of IFN $\gamma$ (Fig. 3). In cultures treated with lower doses of 

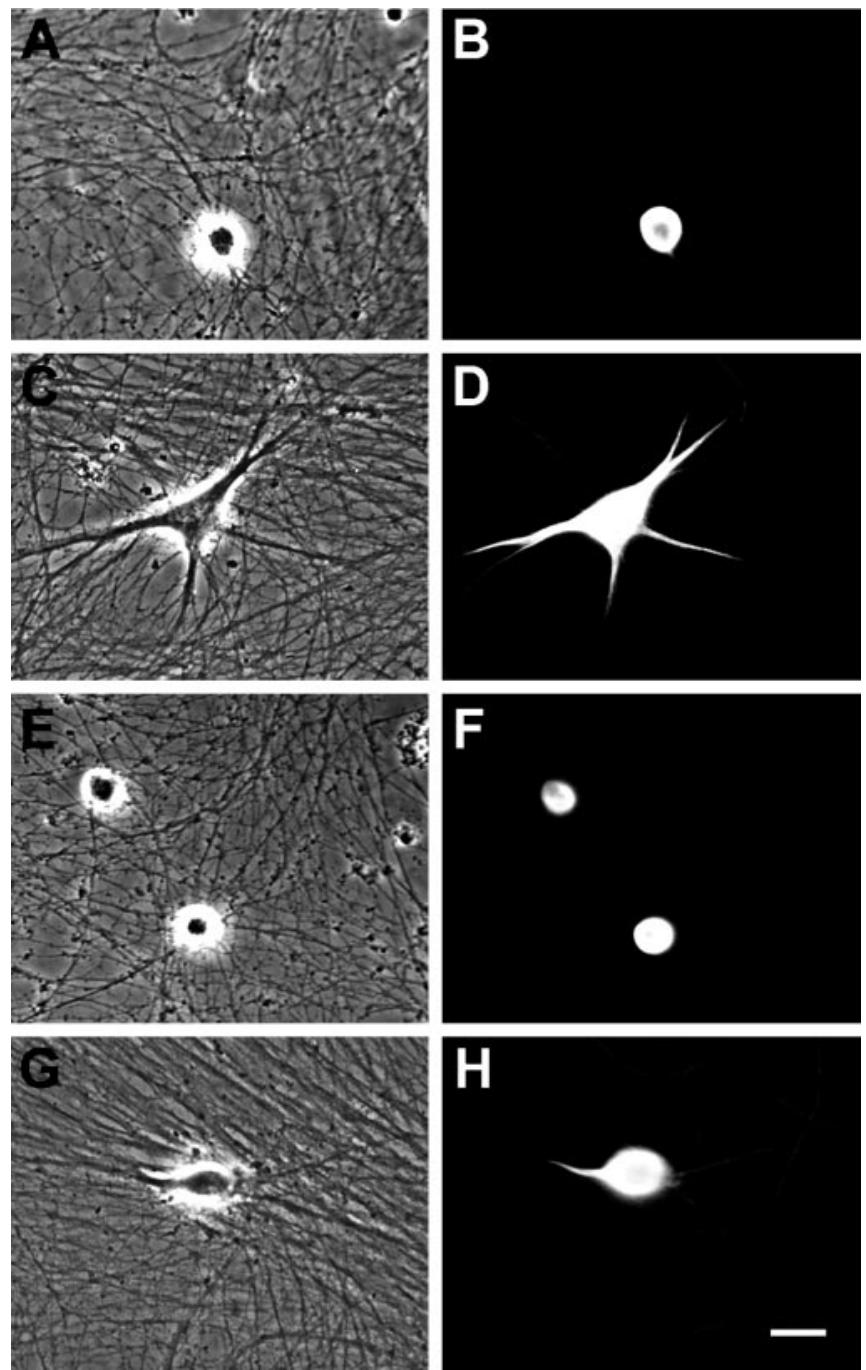

Figure 1. Effect of BMP-7 and IFN $\gamma$ on the morphology of cultured sympathetic neurons. Shown are phase-contrast $(A, C, E, G)$ and fluorescence $(B, D, F, H)$ micrographs of neurons immunostained with a monoclonal antibody $(\mathrm{mAb})$ to MAP-2 after $5 \mathrm{~d}$ of treatment. Neurons grown in control medium lacked dendrites $(A, B)$. Exposure to BMP-7 $(5 \mathrm{ng} / \mathrm{ml})$ caused the neurons to form multiple dendrites $(C, D)$. IFN $\gamma(10 \mathrm{ng} / \mathrm{ml})$ alone had no effect on dendritic outgrowth $(E, F)$, but it inhibited the growth of these processes in cultures that were exposed to BMP-7 $(G, H)$. Scale bar, $30 \mu \mathrm{m}$.

BMP-7 (5 ng/ml), the effect was even greater (78\% inhibition). Under these conditions total dendritic length also was reduced (Fig. 2). Inhibition was observed with concentrations of IFN $\gamma$ as low as $0.1 \mathrm{ng} / \mathrm{ml}$; the $\mathrm{ID}_{50}$ (dose causing half-maximal inhibition) was $\sim 1 \mathrm{ng} / \mathrm{ml}$ (Fig. 3). IFN $\gamma$-induced inhibition of initial dendritic growth was long lasting, with no sign of reversal even after 2 weeks of continuous exposure (Fig. 2), and IFN $\gamma$ also blocked the effects of BMP-2 and BMP-6 (data not shown), suggesting that it interacts with a common component of the BMP signaling pathway.

\section{IFN $\gamma$ inhibits synapse formation and dendritic growth in hippocampal neurons}

To determine whether IFN $\gamma$ also inhibits dendritic growth in CNS neurons, we examined its effects on cultured embryonic hippocampal neurons. These neurons differ from sympathetic neurons in that they spontaneously form dendrites in the absence
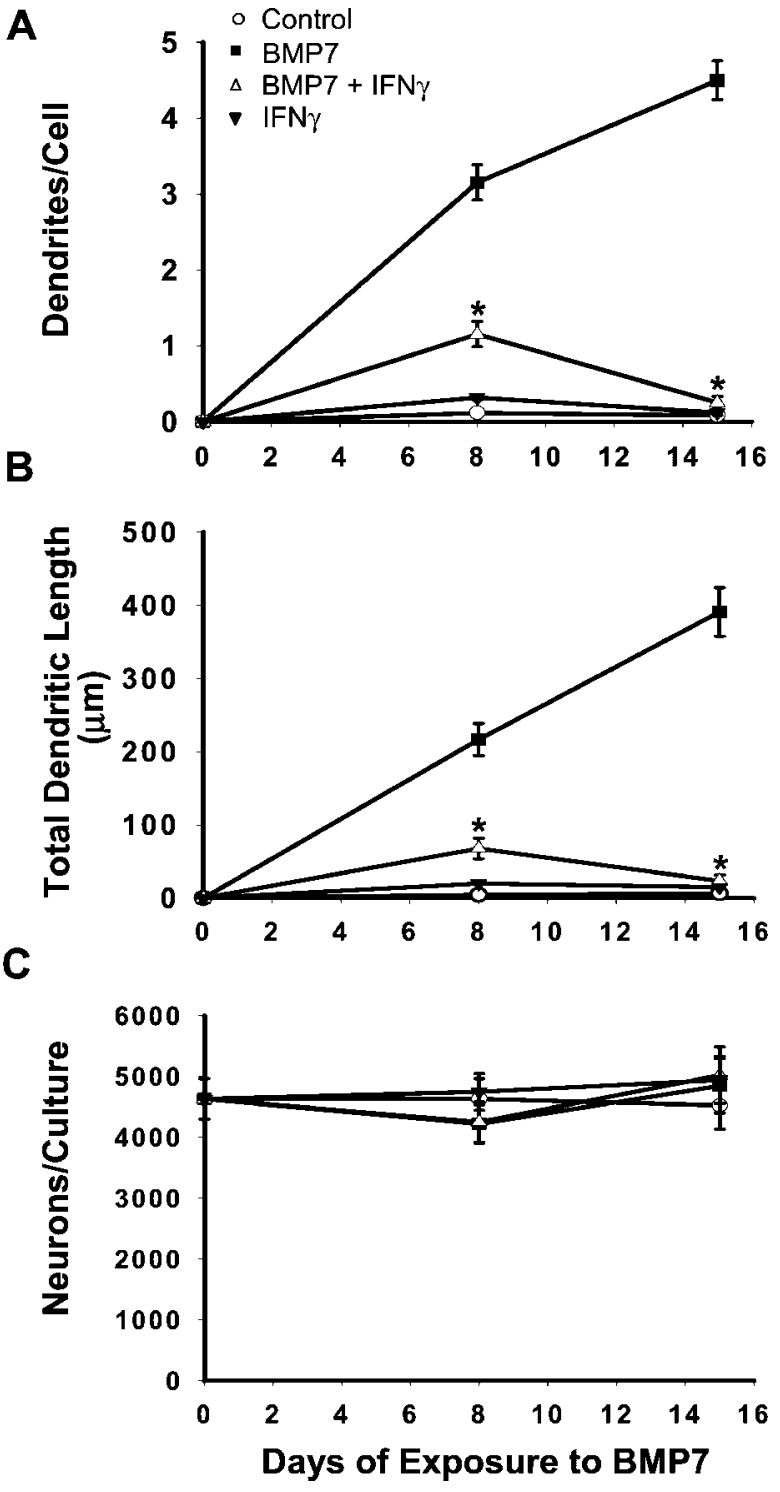

Figure 2. IFN $\gamma$ inhibits BMP-7-induced dendritic outgrowth. Sympathetic neurons were treated with BMP-7 $(5 \mathrm{ng} / \mathrm{ml})$, IFN $\gamma(10 \mathrm{ng} / \mathrm{ml})$, or BMP-7 and IFN $\gamma$. On days 8 and 15, cellular morphology $(n \geq 60$ cells/condition) was visualized by immunostaining with $\mathrm{mAb}$ to MAP-2. $A$, Number of dendrites per cell. $B$, Total dendritic length. $C$, Number of MAP-2-positive cells per culture. ${ }^{*} p<0.05$ versus BMP-7.

of exogenous BMPs. Exposure to IFN $\gamma$ reduced hippocampal dendritic growth by $36 \%$ (Fig. $4 B$ ). In addition, treatment with IFN $\gamma$ caused a $37 \%$ decrease in the number of SV-2-positive (Fig. $4 C$ ) and synaptophysin-positive (data not shown) varicosities associated with MAP-2-positive dendrites. Thus in CNS neurons the IFN $\gamma$-induced inhibition of dendritic growth is associated with a proportionate decrease in the formation of synapses.

\section{IFN $\boldsymbol{\gamma}$ induces retraction of existing dendritic process}

In addition to examining the effects of IFN $\gamma$ on initial process outgrowth, we also wanted to know whether it affected existing processes. Therefore, dendritic growth was initially induced in cultures of sympathetic neurons by a $5 \mathrm{~d}$ exposure to BMP-7; this was followed by treatment for $6 \mathrm{~d}$ with either BMP-7 alone or BMP-7 with IFN $\gamma$ (Fig. 5). In cells treated with an intermediate 


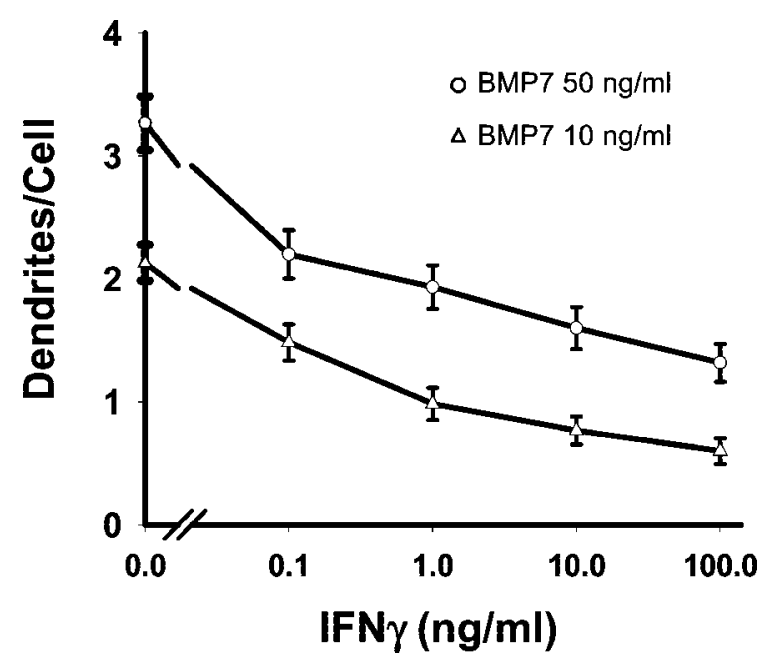

Figure 3. Dose-dependent inhibition of dendritic outgrowth by IFN $\gamma$. The effects of varying concentrations of IFN $\gamma$ were assessed in cultures treated with either a maximally effective dose of BMP-7 $(50 \mathrm{ng} / \mathrm{ml}$; open circles $)$ or one close to the $\mathrm{ED}_{50}(5 \mathrm{ng} / \mathrm{ml}$; open triangles $)$. After $5 \mathrm{~d}$ of cotreatment with BMP-7 and IFN $\gamma$ cultures were immunostained with $\mathrm{mAb}$ to MAP-2.

dose of BMP-7 (5 ng/ml), IFN $\gamma$ caused an $\sim 90 \%$ decrease in both the number of dendrites per cell and in total dendritic length. Dendritic retraction was also prominent in cultures exposed to a maximally effective dose of BMP-7, with $\sim 80 \%$ of the processes being eliminated in the presence of IFN $\gamma$. Thus the effect of IFN $\gamma$ on dendritic retraction is at least as great as that on initial extension. Time course studies revealed that dendritic retraction was a slow process that began $24-48 \mathrm{hr}$ after initial IFN $\gamma$ exposure and required at least $4 \mathrm{~d}$ for completion (data not shown).

\section{IFN $\boldsymbol{\gamma}$ does not affect axonal growth or cell number}

To assess the specificity of action of IFN $\gamma$, we first examined its effect on the survival of sympathetic neurons. In all experiments neuronal number remained essentially constant (Figs. 2, 5), indicating that IFN $\gamma$ was not acting by promoting the survival of a subpopulation of neurons. To assess specificity further, we examined the effects of IFN $\gamma$ on axonal growth. To allow induction of IF $\gamma$-sensitive genes, explants of sympathetic ganglion were initially maintained for $2 \mathrm{~d}$ in the presence or absence of IFN $\gamma$. After this pretreatment ganglia were dissociated, and the cells were plated onto coverslips; treatment with either control medium or IFN $\gamma$ was resumed. Axonal length was assessed after $12 \mathrm{hr}$ of growth and found to be unaltered by exposure to IFN $\gamma$ (Fig. 6).

To explore further the possibility that IFN $\gamma$ selectively affects dendritic processes, Western blot analysis was used to compare the expression of cytoskeletal proteins (Fig. 6). The expression of tau, which is found primarily in axons, was not affected by IFN $\gamma$. The expression of actin, which is involved in both dendritic and axonal development, was elevated by treatment with BMP-7 and only slightly decreased by IFN $\gamma$, as was the expression of the dendritic protein MAP-2 (data not shown). Moreover, the total protein content of control and BMP-7-treated cultures was unaffected by IFN $\gamma$ exposure (data not shown), indicating that overall cellular health is not affected by IFN $\gamma$. These results suggest that IFN $\gamma$ selectively affects dendritic outgrowth.

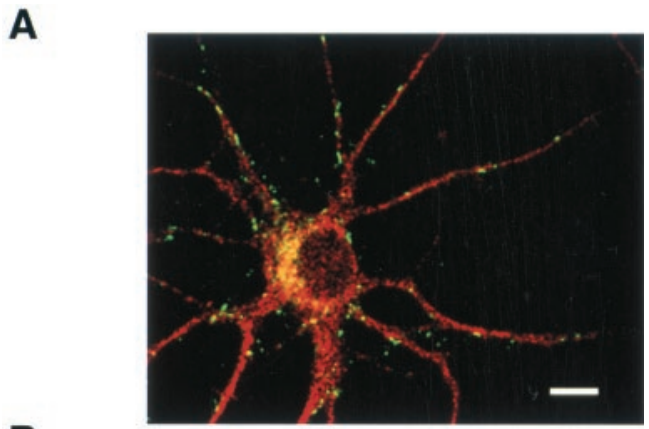

B
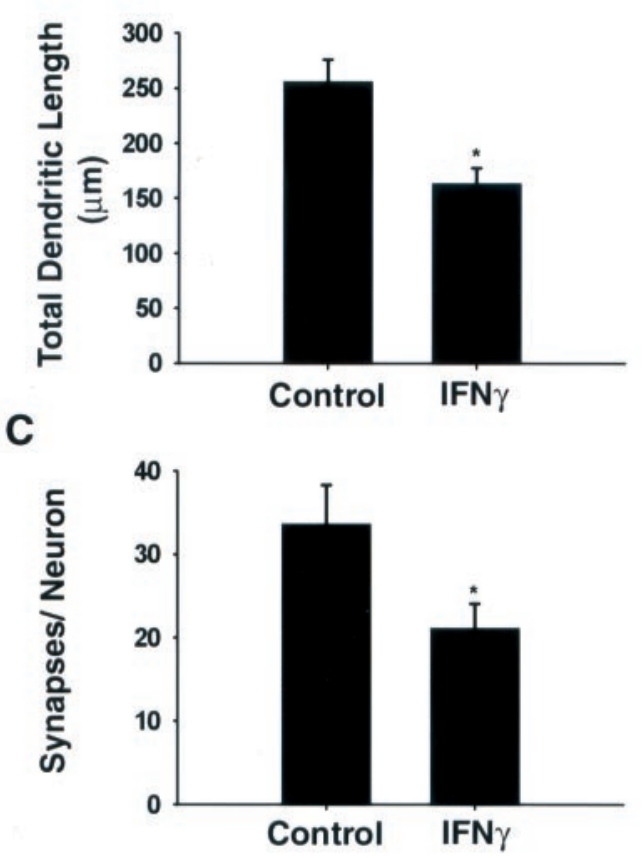

Figure 4. IFN $\gamma$ inhibits dendritic growth and synaptogenesis in hippocampal neurons. Hippocampal neurons were grown in the absence or presence of IFN $\gamma(30 \mathrm{ng} / \mathrm{ml})$ for $5 \mathrm{~d}$. $A$, Fluorescence micrograph of neuron grown in control medium. Dendritic morphology $(n>25$ cells/ condition) and presynaptic specializations were analyzed by doublelabeled immunostaining with antibodies to MAP-2 (red) and SV-2 (green). Cells were examined with a Bio-Rad confocal microscope, using $1 \mu \mathrm{m}$ optical sections. SV-2-positive puncta that are associated with dendrites have been shown previously to represent sites of synaptic contact (Fletcher et al., 1991). Scale bar, $10 \mu \mathrm{m}$. B, Total dendritic length. $C$, Synapses per neuron. ${ }^{*} p<0.05$ versus control.

\section{Comparison of the effects of IFN $\gamma$ and other cytokines}

Like IFN $\gamma$, TNF $\alpha$, IL- $1 \beta$, and IFN $\beta$ have been detected at sites of inflammatory reactions in the nervous system (Taupin et al., 1993; Rothwell and Hopkins, 1995; Ensoli et al., 1999). We therefore compared their effects on dendritic growth. Neither inhibition of initial dendritic outgrowth (Table 1) nor dendritic retraction (Fig. 7) was observed with $\mathrm{TNF} \alpha$, IL-1 $\beta$, or IFN $\beta$. In addition, we found no evidence for potentiation of IFN $\gamma$ action by $\mathrm{TNF} \alpha$ or IL $-1 \beta$.

\section{Involvement of STAT1 in dendritic retraction}

Many cellular responses to IFN $\gamma$ are mediated by activation of the Janus kinase pathway causing the phosphorylation of STAT1, a transcription factor (Farrar and Schreiber, 1993; Bach et al., 1997; Schindler, 1999). To determine whether the effects of IFN $\gamma$ on dendrites required the activation of STAT1, we examined the 

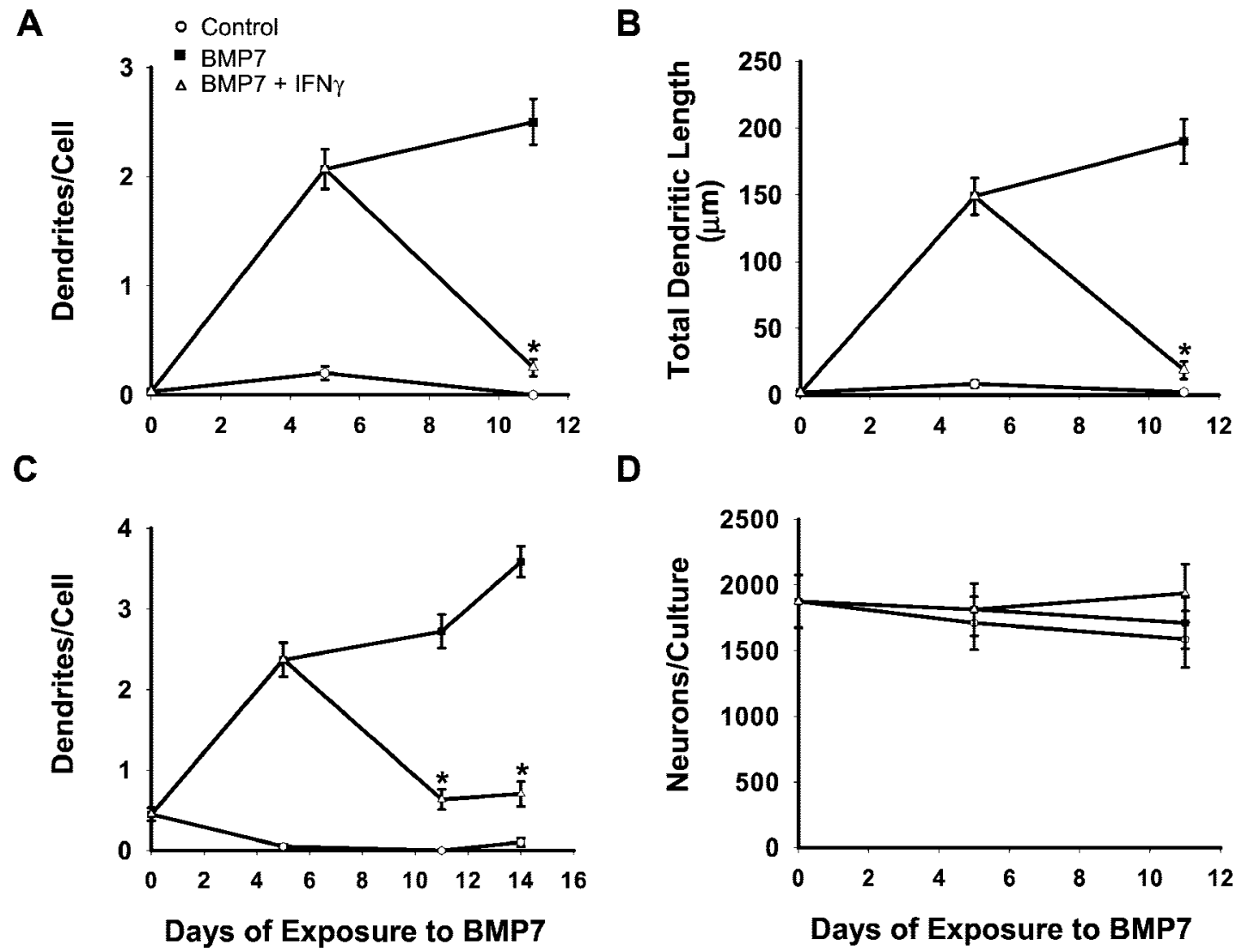

D

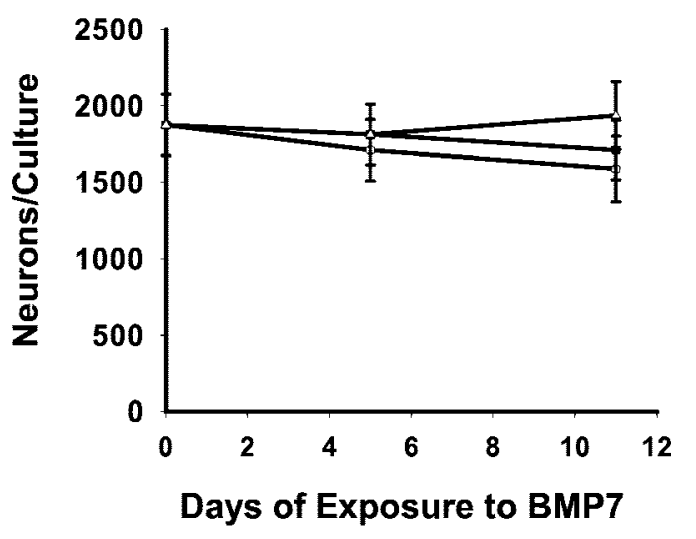

Figure 5. IFN $\gamma$ induces dendritic retraction. Sympathetic neurons were treated initially with $5 \mathrm{ng} / \mathrm{ml} \mathrm{BMP-7}(A, B, D)$ or $20 \mathrm{ng} / \mathrm{ml}(C)$ for $5 \mathrm{~d}$. Subsequently, they were divided into two groups. One was treated continuously with BMP-7, and the other was treated with both IFN $\gamma(10 \mathrm{ng} / \mathrm{ml})$ and BMP7 for an additional $6 \mathrm{~d}$. Dendritic morphology was assessed by immunostaining with mAb to MAP-2 ( $n \geq 60$ cells/condition). $A$, $C$, Number of dendrites per cell. $B$, Total dendritic length. $D$, Number of MAP-2-positive cells per culture. ${ }^{*} p<0.05$ versus BMP-7 on day 5 .

distribution of STAT1 in sympathetic neurons. Immunostaining with an antibody that recognizes phosphorylated STAT1 revealed that IFN $\gamma$ induced the phosphorylation and nuclear translocation of STAT1 (Fig. 8).

We next determined whether transfection with a dominantnegative mutant of STAT1 that cannot be phosphorylated on Tyrosine 701 (Y701F) (Nakajima et al., 1996) reversed the inhibitory effects of IFN $\gamma$ on dendritic outgrowth. Wild-type STAT1 or mutant STAT1 was cotransfected with EGFP to identify the transfected cells. Forty-eight hours after transfection cells were treated with BMP-7 $(10 \mathrm{ng} / \mathrm{ml})$ in the presence or absence of IFN $\gamma(20 \mathrm{ng} / \mathrm{ml})$. Consistent with the previous observation (Fig. 3), IFN $\gamma$ decreased BMP-7-induced dendritic outgrowth by $\sim 80 \%$ in cultures transfected with control vector, indicating that transfection by itself did not change the response of sympathetic neurons to either BMP-7 or IFN $\gamma$ (Fig. 9A). Overexpression of wild-type STAT1 potentiated the inhibition by IFN $\gamma$ and also slightly decreased dendritic outgrowth that was induced by BMP-7. In contrast, transfection of mutant STAT1 itself did not change the response of BMP-7 but significantly reduced the inhibitory effect of IFN $\gamma$ on dendritic sprouting.

Although IFN $\gamma$ predominantly activates STAT1, it also affects STAT3 in some cells (Stephens et al., 1998). Moreover, we observed previously that the activation of STAT3 by LIF blocks dendritic growth in sympathetic neurons (Guo et al., 1999). We therefore determined whether STAT3 plays a role in IFN $\gamma$ induced dendritic inhibition. Overexpression of mutant STAT3 did not affect the dendritic inhibition caused by IFN $\gamma$ (Fig. 9B). In addition, IFN $\gamma$ did not induce nuclear translocation of STAT3 in sympathetic neurons (data not shown). These data strongly suggest that the inhibitory effects of IFN $\gamma$ on dendritic growth require the STAT1 activation and thus transcriptional activity.

\section{Dendrites retract in response to IFN $\gamma$ applied selectively to distal axons}

Because many inflammatory reactions occur in white matter, elevated levels of IFN $\gamma$ often are found in the vicinity of axons at a substantial distance from neuronal somata. Under these conditions IFN $\gamma$ signaling must be retrogradely conveyed to the cell body if it is to affect dendritic morphology. To examine this possibility, we used compartmented cultures originally developed by Campenot (Campenot, 1977; Senger and Campenot, 1997). This culture system allows physical separation of the medium that is bathing cell bodies and proximal processes from the medium that is bathing distal axons and axon terminals (Fig. 10A). Thus IFN $\gamma$ can be applied selectively to distal axons and terminals.

Neurons plated into the center compartment extend axons into the left and right compartments within 5-7 d, and extensive axonal growth is evident in the side chambers within 10-12 d after plating. Neurons maintained in control medium do not extend dendrites; in contrast, neurons whose cell bodies are exposed to BMP-7 $(10 \mathrm{ng} / \mathrm{ml})$ exhibit significant dendritic growth (Fig. 10C). Subsequent addition of IFN $\gamma(10 \mathrm{or} 50 \mathrm{ng} / \mathrm{ml})$ to the medium of the right compartment, which contains distal axons 
A

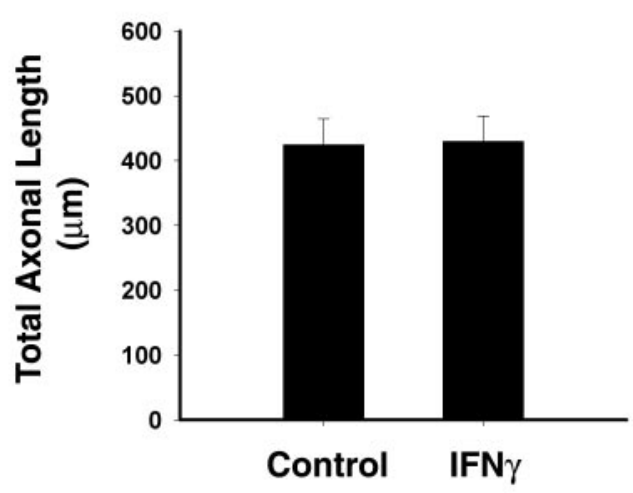

B

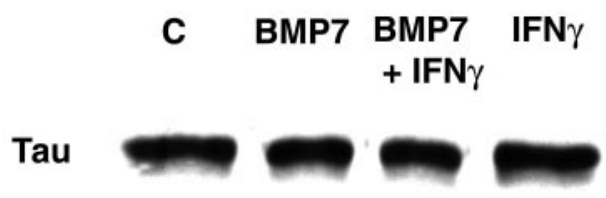

Actin

Figure 6. Lack of effect of IFN $\gamma$ on axonal growth. $A$, Explants of superior cervical ganglia were maintained for $2 \mathrm{~d}$ in the presence or absence of IFN $\gamma(10 \mathrm{ng} / \mathrm{ml})$. Subsequently, the ganglia were dissociated, and cells were plated onto coverslips coated with laminin $(2 \mu \mathrm{g} / \mathrm{ml})$. Cells then were exposed continuously to control medium or IFN $\gamma$ for $12 \mathrm{hr}$. Axons were immunostained with $\mathrm{mAb}$ that recognizes phosphorylated forms of $\mathrm{H}$ and $\mathrm{M}$ neurofilament subunits. Cellular morphology was analyzed using Image software ( $n \geq 60$ cells/condition). $B$, Cultures were treated with BMP-7 $(5 \mathrm{ng} / \mathrm{ml})$ for $8 \mathrm{~d}$; during the last $3 \mathrm{~d}$ of treatment some were also exposed to IFN $\gamma(10 \mathrm{ng} / \mathrm{ml})$. Expression of cytoskeletal proteins was detected by Western blotting with mAb to tau and a polyclonal antibody to actin. Equal amounts of protein were loaded into each lane.

Table 1. Effect of inflammatory cytokines on initial dendritic outgrowth

Cytokines

Dendrites/cell

BMP-7

$2.02 \pm 0.18$

$\mathrm{BMP}-7+\mathrm{IFN} \gamma$

$0.62 \pm 0.12 *$

BMP-7 + IFN $\beta$

$2.20 \pm 0.20$

BMP-7 + TNF $\alpha$

$1.98 \pm 0.17$

BMP-7 + IL-1 $\beta$

$1.95 \pm 0.19$

$\overline{\text { Cultures of sympathetic neurons were treated with BMP-7 }(5 \mathrm{ng} / \mathrm{ml}) \text { either alone or }}$ in combination with one of the following agents for $5 \mathrm{~d}$ : IFN $\gamma(10 \mathrm{ng} / \mathrm{ml}), \mathrm{TNF} \alpha(10$ $\mathrm{ng} / \mathrm{ml}), \mathrm{IL}-1 \beta(10 \mathrm{ng} / \mathrm{ml})$, or IFN $\beta(10 \mathrm{ng} / \mathrm{ml})$. Dendritic morphology was analyzed after immunostaining with mAb to MAP2. ${ }^{*} p<0.05$ versus BMP-7.

and axon terminals (Fig. 10B), elicits a dose-dependent reduction in the total dendritic length of those neurons that extend axons into the right compartment (Fig. 10C). Neurons that extended axons into the right compartment were identified by the uptake and retrograde transport of fluorescent beads (Fluorobeads, F8795, $8 \mu \mathrm{l} / \mathrm{ml}$; Molecular Probes, Eugene, OR) added to the right chamber 12-16 hr before the cultures were fixed and immunostained for dendritic growth. Comparative analyses of dendritic growth in fluorescently labeled neurons versus nonlabeled

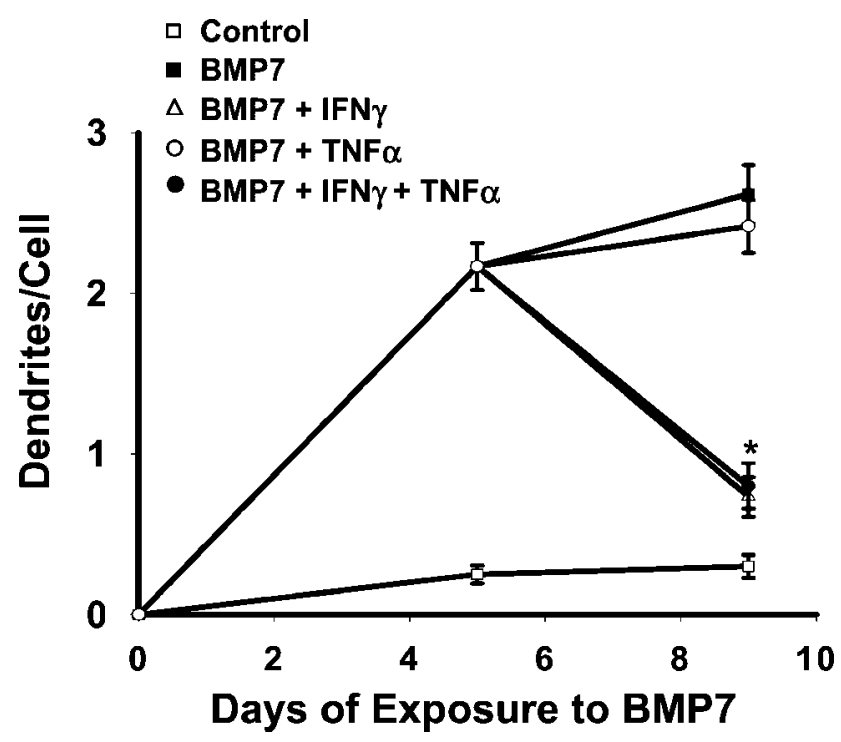

Figure 7. TNF $\alpha$ does not potentiate the effect of IFN $\gamma$ on dendritic retraction. Sympathetic neurons were exposed to BMP-7 $(5 \mathrm{ng} / \mathrm{ml})$ for $9 \mathrm{~d}$. Beginning on day 5, some of them were treated additionally with IF $\gamma(10 \mathrm{ng} / \mathrm{ml}), \mathrm{TNF} \alpha(10 \mathrm{ng} / \mathrm{ml})$, or the combination of both of the agents. On day 9 , dendritic morphology was assessed by immunostaining with $\mathrm{mAb}$ to MAP-2. * $p<0.05$ versus BMP-7 on day 5 .
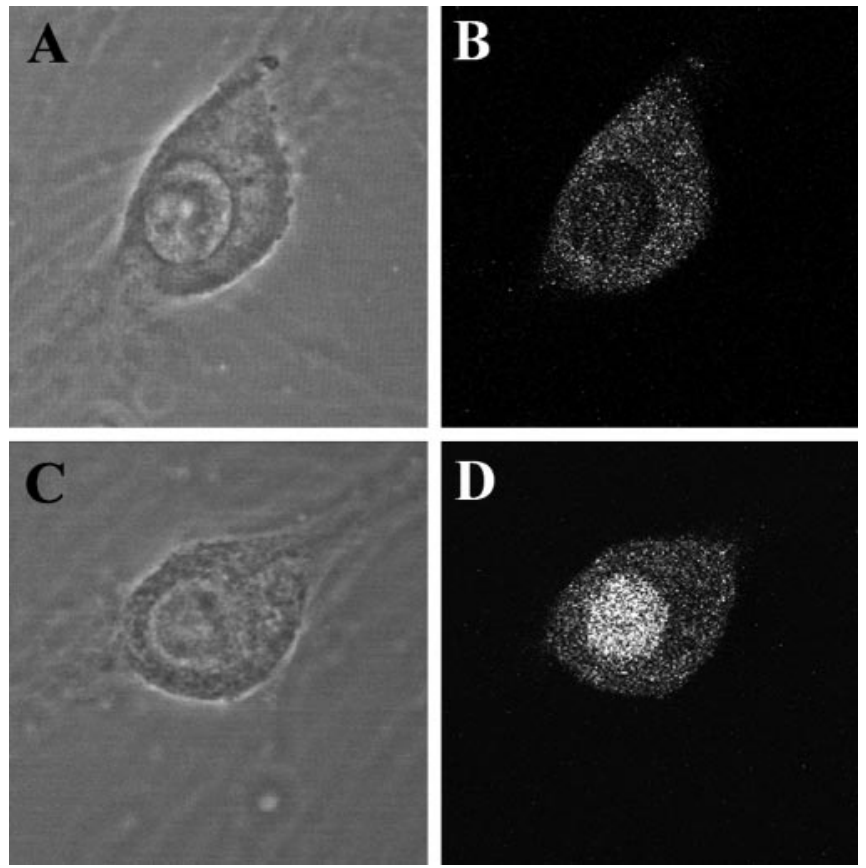

Figure 8. IFN $\gamma$ induces phosphorylation and nuclear translocation of STAT1. Sympathetic neurons were treated with BMP-7 $(5 \mathrm{ng} / \mathrm{ml})$ for $5 \mathrm{~d}$. Subsequently, IFN $\gamma(10 \mathrm{ng} / \mathrm{ml})$ was added for $1 \mathrm{hr}$ to the medium of some cultures $(C, D)$, whereas others were treated with BMP-7 alone $(A, B)$. The cellular location of STAT1 was detected by immunostaining with an antibody that reacts with a phosphorylated form of STAT1 (Tyr 701); the cells were examined with a Bio-Rad confocal microscope, using $1 \mu \mathrm{m}$ optical sections. Shown are phase-contrast $(A, C)$ and fluorescence $(B, D)$ micrographs.

neurons (e.g., neurons that extend axons only into the left compartment) indicated that dendritic growth in the nonlabeled neurons was not decreased in response to the addition of IFN $\gamma$ to the right compartment (data not shown). This observation confirms 
A

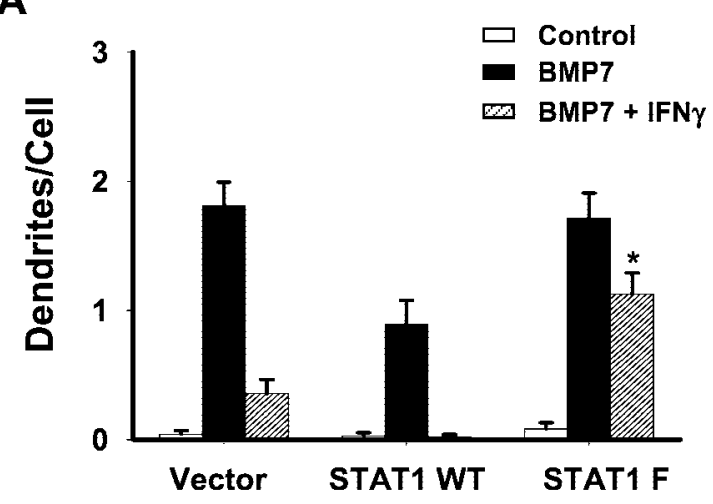

B

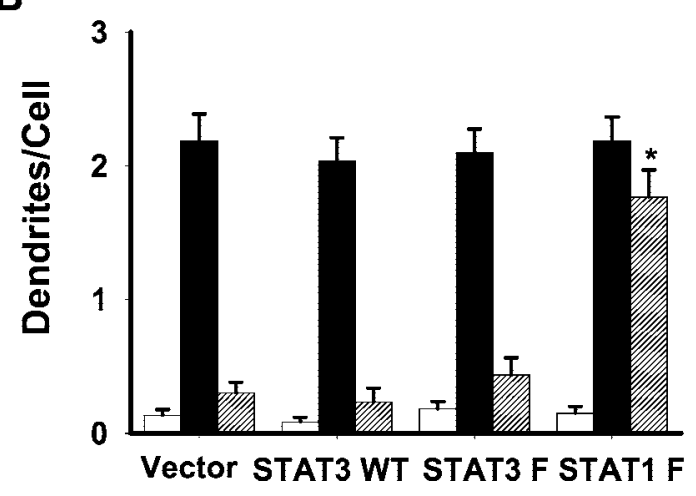

Figure 9. Dominant-negative STAT1 overcomes the inhibitory effect of IFN $\gamma$ on dendrites. Sympathetic neurons were cotransfected with plasmids containing the genes for EGFP and $(A)$ wild-type $(S T A T 1 W T)$ or mutant STAT1 (STAT1 $F$ ) or $(B)$ wild-type or mutant STAT3 or mutant STAT1 by Lipofectamine reagent. After $48 \mathrm{hr}$ the cells were treated with BMP-7 (10 ng/ml), IFN $\gamma(20 \mathrm{ng} / \mathrm{ml})$, or BMP-7 and IFN $\gamma$. On day 6 , cellular morphology was visualized by immunostaining with $\mathrm{mAb}$ to MAP-2. Transfected cells were assessed by the expression of EGFP. ${ }^{*} p<$ 0.05 versus BMP-7 and IFN $\gamma$ in the culture transfected with the control vector.

that the effect of IFN $\gamma$ on labeled neurons was not mediated by IFN $\gamma$ leaking into the center compartment.

\section{DISCUSSION}

Expression of IFN $\gamma$ is elevated in murine trisomy 16, a model of human Down's syndrome (Torre et al., 1995; Hallam et al., 2000), and overexpression of IFN $\gamma$ induces cerebellar and hippocampal malformations in transgenic mice (Corbin et al., 1996; LaFerla et al., 2000). IFN $\gamma$ is known to regulate the maturation of glia (Merrill et al., 1993; Popko et al., 1997; Benn et al., 2001), and so it is possible that the developmental defects induced by IFN $\gamma$ exposure arise secondarily from its actions on these cells. Our results indicate, however, that IFN $\gamma$ also has direct inhibitory effects on neurons and adversely affects their growth in the absence of non-neuronal cells. These observations suggest a novel mechanism by which IFN $\gamma$ interferes with neural development, and they contrast with previous studies that have reported primarily beneficial effects of IFN $\gamma$ on the growth and differentiation of isolated neural cell populations (Erkman et al., 1989; Barish et al., 1991; Jonakait et al., 1994).

Exposure to IFN $\gamma$ produced a profound and long-lasting inhibition of BMP-7-induced dendritic growth in cultures of sympathetic neurons. This effect did not reflect compromised cellular viability or health because it was not associated with changes in
A

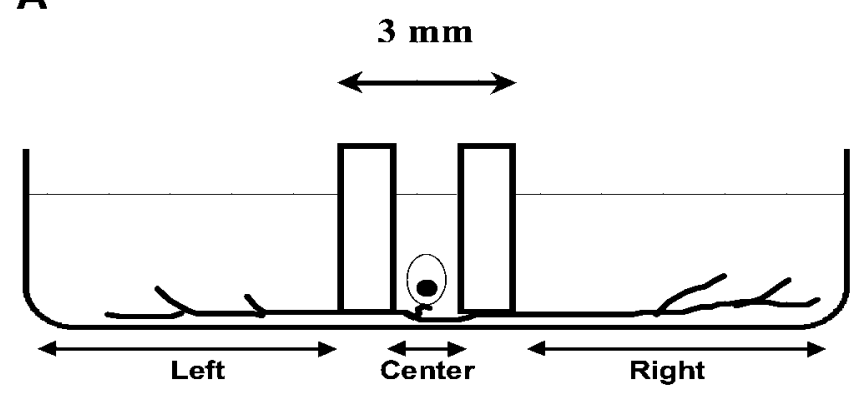

B

\begin{tabular}{|c|c|c|c|c|c|c|}
\hline & \multicolumn{3}{|c|}{ Days 1-3 } & \multicolumn{3}{|c|}{ Days 4-7 } \\
\hline & Left & Center & Right & Left & Center & Right \\
\hline $\begin{array}{c}\text { Negative } \\
\text { Control }\end{array}$ & $\mathrm{C}_{2}$ & $\mathrm{C}_{2}$ & $\mathrm{C}_{2}$ & $\mathrm{C}_{2}$ & $\mathrm{C}_{2}$ & $\mathrm{C}_{2}$ \\
\hline $\begin{array}{l}\text { Positive } \\
\text { Control }\end{array}$ & $\mathbf{C}_{2}$ & BMP7 & $\mathbf{C}_{2}$ & $\mathrm{C}_{2}$ & BMP7 & $\mathrm{C}_{2}$ \\
\hline $\begin{array}{c}\text { Experiment } \\
1\end{array}$ & $\mathrm{C}_{2}$ & BMP7 & $\mathrm{C}_{2}$ & $\mathrm{C}_{2}$ & BMP7 & $\begin{array}{c}\text { IFN } \gamma \\
(10 \mathrm{ng})\end{array}$ \\
\hline $\begin{array}{c}\text { Experiment } \\
2\end{array}$ & $\mathrm{C}_{2}$ & BMP7 & $\mathrm{C}_{2}$ & $C_{2}$ & BMP7 & $\begin{array}{c}\text { IFN } \gamma \\
(50 \mathrm{ng})\end{array}$ \\
\hline
\end{tabular}

C

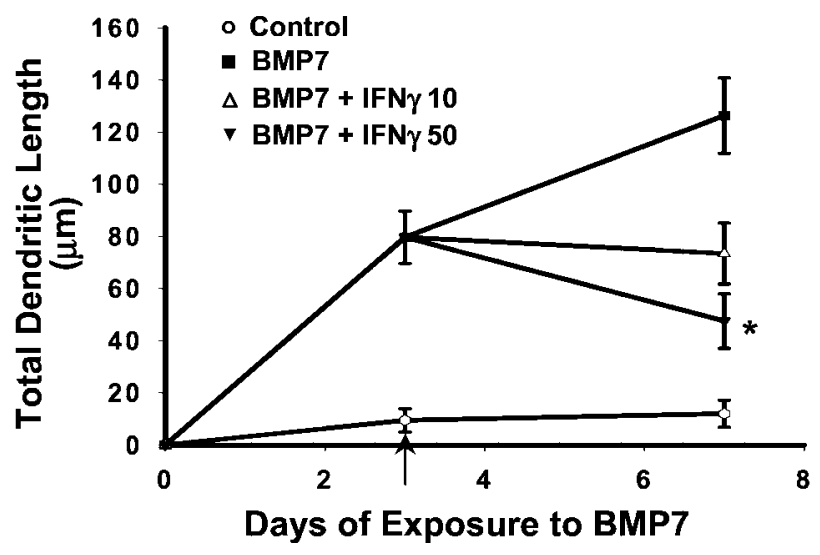

Figure 10. Dendritic retraction in response to retrograde signaling by IFN $\gamma . A$, Schematic representation of the three-compartment culture of sympathetic neurons. Dissociated neurons were plated in the Center compartment, and axons extended into the Left and Right compartments. $B$, Negative control cultures were maintained in control medium $\left(C_{2}\right)$ in the absence of BMP-7 or IFN $\gamma$; positive control and experimental cultures were exposed to BMP-7 $(10 \mathrm{ng} / \mathrm{ml})$ added to $\mathrm{C}_{2}$ in the Center compartment for $7 \mathrm{~d}$. Three days after the addition of BMP-7, IFN $\gamma(10$ or $50 \mathrm{ng} / \mathrm{ml}$ ) was added to the $\mathrm{C}_{2}$ in the Right compartment of experimental cultures (indicated by the arrow in $C$ ). Then $4 \mathrm{~d}$ later, dendritic growth was quantified in cultures immunostained with mAb to MAP-2 $(n \geq 60$ cells/ condition). Addition of IFN $\gamma$ to the distal axons and axon terminals caused a dose-dependent reduction in total dendritic length $(C)$. $* p<0.05$ versus BMP-7 on day 7.

cell number, axon elongation, or the expression of tau, a protein found primarily in axons (Binder et al., 1985; Brion et al., 1988). Rather, IFN $\gamma$ had a selective morphogenic effect on the development of a restricted cellular compartment. Although smaller in 
magnitude, a qualitatively similar effect of IFN $\gamma$ was observed on the growth of dendrites in cultures of hippocampal neurons, a population of neurons that was not exposed to BMP-7 and spontaneously forms dendrites in its absence (Banker and Waxman, 1988). Thus it appears that IFN $\gamma$ inhibits dendritic growth in cells derived from both the central and peripheral nervous systems and that it affects both BMP-7-induced and spontaneous dendritic growth. It is, therefore, likely that IFN $\gamma$ has widespread effects on dendritic growth in the nervous system.

Dendrites are the primary site of synapse formation in the mammalian nervous system (Purves, 1988), and so agents that inhibit dendritic growth would be expected to reduce synapse formation. Although sympathetic neurons form functional synapses with each other in tissue culture, they do not make such connections with each other in vivo (O'Lague et al., 1974; Higgins et al., 1981). We therefore did not think it appropriate to examine the effect of cytokines on synapse formation in the cultured sympathetic neurons. On the other hand, hippocampal neurons are known to form synaptic contacts with one another in vivo (Swanson et al., 1987) and they also do so in vitro (Bartlett and Banker, 1984; Fletcher et al., 1991). In such cultures, treatment with IFN $\gamma$ caused a reduction in the number of SV-2-positive and of synaptophysin-positive varicosities that were associated with MAP-2-positive dendrites. Because such varicosities have been found previously to represent sites of transmitter uptake and release (Fletcher et al., 1991; Matteoli et al., 1992; Pyle et al., 1999), these observations indicate that IFN $\gamma$ reduces synapse formation, at least in neurons from the CNS. In addition, Vikman et al. (2001) have reported recently that, in mixed neural glial cultures, IFN $\gamma$ exposure also causes a decrease in AMPA receptor clustering, suggesting that IFN $\gamma$-induced decreases in synapse number may be aggravated by other functional changes.

In addition to having effects on initial process outgrowth, prolonged exposure to IFN $\gamma$ also causes sympathetic neurons to retract most of their existing dendrites, leading to an $\sim 90 \%$ decrease in the size of the dendritic arbor. These effects were observed with concentrations of IFN $\gamma$ similar to those detected after viral infection in humans and mice (Lebon et al., 1988; Weller et al., 1991; Rockstroh et al., 1998). IFN $\gamma$ plays a critical role in viral clearance from the CNS (Binder and Griffin, 2001) and chronic viral infections, such as those associated with HIV, lead to long-term increases in the expression of IFN $\gamma$ (Fuchs et al., 1991; Fan et al., 1993). Such chronic infections also induce dendritic atrophy (Masliah et al., 1997; Everall et al., 1999; Montgomery et al., 1999). It is, therefore, possible that IFN $\gamma$ has a dual-edged effect in the response to viral infection: it promotes clearance of virions but also contributes to the pathology, and especially the dementia, by inducing dendritic retraction. In addition, it is important to note that elevated IFN $\gamma$ expression (Kiefer et al., 1991; Kristensson et al., 1994; Lau and Yu, 2001; Li et al., 2001) occurs coincident with dendritic retraction (Sumner and Watson, 1971; Purves, 1975; Yawo, 1987; Kudo et al., 1993; Park et al., 1996) in many types of acute inflammatory reactions, including those triggered by trauma, stroke, and axotomy.

Many of the effects of IFN $\gamma$ are mediated by activation of the STAT1 signaling pathway (Farrar and Schreiber, 1993; Bach et al., 1997; Schindler, 1999). However, there is also evidence for the involvement of STAT3 in some IFN $\gamma$ actions (Stephens et al., 1998) as well as for STAT-independent effects (Ramana et al., 2000; Gil et al., 2001). Our examination of the pathways involved in IFN $\gamma$-induced dendritic retraction revealed that IFN $\gamma$ stimulated the phosphorylation and nuclear translocation of STAT1, but not STAT3, in cultures of sympathetic neurons. In addition, dendritic retraction was blocked by expression of a dominantnegative STAT1 construct, but not by a similar STAT3 construct, strongly suggesting that the former is the primary signaling pathway involved in process elimination. We reported previously that members of the IL- 6 family of cytokines induce dendritic retraction via activation of STAT3 (Guo et al., 1999). Thus there appear to be independent routes by which these two classes of cytokines can cause dendritic atrophy, and this raises the possibility of synergistic interactions. In this respect it is important to note that there is frequent coexpression of IFN $\gamma$ with IL-6-related cytokines in inflammatory reactions. For example, astrocytes and Schwann cells release IFN $\gamma$ and IL-6 after traumatic injury or ischemia (Banner and Patterson, 1994; Curtis et al., 1994; Sun et al., 1996; Lau and Yu, 2001). The pathways leading from STAT activation to dendritic retraction are unclear, but there is reason to suspect the involvement of the paralogous transcriptional regulators p300 and CREB binding protein (CBP). BMP-induced dendritic growth requires the phosphorylation and nuclear translocation of SMAD1 (Guo et al., 2001), and activated SMADs are known to bind to p300 (Janknecht et al., 1998; Kawabata et al., 1999). Activated STATs also bind p300, and the expression of type I collagen that is induced by SMAD3 is negatively regulated by STAT1 activation (Ghosh et al., 2001). Thus competition between activated STATs and SMADs for interaction with limiting amounts of cellular p300/CBP may account for some of the effects of IFN $\gamma$ on dendritic growth in sympathetic neurons.

Target-derived growth factors regulate the development of many, if not most, classes of neurons (Oppenheim, 1991; Korsching, 1993). Such agents typically signal in a retrograde manner, with information being conveyed from distal axons to neural somata. Previous studies have focused on the beneficial nature of retrograde signals and have emphasized their role in promoting neuronal survival (Hendry and Campbell, 1976; Chun and Patterson, 1977) and differentiation (Hendry, 1977) and in stimulating initial process extension (Campenot, 1977, 1987) and regeneration (Smith and Skene, 1997; Cafferty et al., 2001). In contrast, observations of sympathetic neurons grown in compartmented Campenot chambers indicate that, when IFN $\gamma$ was applied to compartments containing distal axons, it led to dendritic retraction in compartments containing cell bodies and proximal processes. This is a novel variant of retrograde interaction in which cytokine-induced signals that are generated in axon terminals cause atrophy of other parts of the cell. It implies that retrograde interactions with proinflammatory cytokines can be "dystrophic" and can lead to elimination of distant processes and their associated synaptic contacts.

Retrograde dystrophic interactions could play an important role in neural disease because they convey information about injury or inflammation in one part of the brain to another, thereby eliciting reactive changes in distal regions. For example, axotomy induces the expression of IFN $\gamma$ (Kiefer et al., 1991; Kristensson et al., 1994) and also causes dendritic retraction (Purves, 1975; Yawo, 1987). Because retrograde effects of IFN $\gamma$ induce dendritic retraction in vitro, it seems likely to contribute to this process in vivo. Similarly, in MS, IFN $\gamma$ is highly expressed in demyelinating lesions in white matter (Traugott and Lebon, 1988; Popko et al., 1997), whereas dendritic atrophy has been observed in gray matter (Peterson et al., 2001). Retrograde effects of IFN $\gamma$ acting on distal axons provide a potential mechanism for linking these phenomena and for explaining some of the cognitive deficits that are manifest in this disease (Rao et al., 1991; Ron et al., 
1991). The mechanisms underlying such retrograde interactions are currently unclear, and it will be important to determine whether they involve retrograde transport of IFN $\gamma$, its receptor, STAT1, or some combinations of these signaling elements (Ahn et al., 2000).

\section{REFERENCES}

Ahn S, Riccio A, Ginty DD (2000) Spatial considerations for stimulusdependent transcription in neurons. Annu Rev Physiol 62:803-823.

Bach EA, Aguet M, Schreiber RD (1997) The IFN $\gamma$ receptor: a paradigm for cytokine receptor signaling. Annu Rev Immunol 15:563-591.

Bading H, Greenberg ME (1991) Stimulation of protein tyrosine phosphorylation by NMDA receptor activation. Science 253:912-914.

Banker GA, Waxman AB (1988) Hippocampal neurons generate natural shapes in cell culture. In: Intrinsic determinants of neuronal form and function (Lasek RJ, Black MM, eds), pp 61-82. New York: Liss.

Banner LR, Patterson PH (1994) Major changes in the expression of the mRNAs for cholinergic differentiation factor/leukemia inhibitory factor and its receptor after injury to adult peripheral nerves and ganglia. Proc Natl Acad Sci USA 91:7109-7113.

Barish ME, Mansdorf NB, Raissdana SS (1991) Gamma-interferon promotes differentiation of cultured cortical and hippocampal neurons. Dev Biol 144:412-423.

Bartlett WP, Banker GA (1984) An electron microscopic study of the development of axons and dendrites by hippocampal neurons in culture. II. Synaptic relationships. J Neurosci 4:1954-1965.

Benn T, Halfpenny C, Scolding N (2001) Glial cells as targets for cytotoxic immune mediators. Glia 36:200-211.

Binder GK, Griffin DE (2001) Interferon-gamma-mediated site-specific clearance of alphavirus from CNS neurons. Science 293:303-306.

Binder LI, Frankfurter A, Rebhun LI (1985) The distribution of tau in the mammalian central nervous system. J Cell Biol 101:1371-1378.

Boehm U, Klamp T, Groot M, Howard JC (1997) Cellular responses to interferon-gamma. Annu Rev Immunol 15:749-795.

Brewer GJ, Torricelli JR, Evege EK, Price PJ (1993) Optimized survival of hippocampal neurons in B27-supplemented Neurobasal, a new serum-free medium combination. J Neurosci Res 35:567-576.

Brion JP, Guilleminot J, Couchie D, Flament-Durand J, Nunez J (1988) Both adult and juvenile tau microtubule-associated proteins are axon specific in the developing and adult rat cerebellum. Neuroscience 25:139-146.

Bruckenstein DA, Higgins D (1988a) Morphological differentiation of embryonic rat sympathetic neurons in tissue culture. I. Conditions under which neurons form axons but not dendrites. Dev Biol 128:324-336.

Bruckenstein DA, Higgins D (1988b) Morphological differentiation of embryonic rat sympathetic neurons in tissue culture. II. Serum promotes dendritic growth. Dev Biol 128:337-348.

Buckley KM, Kelly RB (1985) Identification of a transmembrane glycoprotein specific for secretory vesicles of neurons and endocrine cells. J Cell Biol 100:1284-1294.

Cafferty WB, Gardiner NJ, Gavazzi I, Powell J, McMahon SB, Heath JK, Munson J, Cohen J, Thompson SW (2001) Leukemia inhibitory factor determines the growth status of injured adult sensory neurons. J Neurosci 21:7161-7170.

Campenot RB (1977) Local control of neurite development by nerve growth factor. Proc Natl Acad Sci USA 74:4516-4519.

Campenot RB (1987) Local control of neurite sprouting in cultured sympathetic neurons by nerve growth factor. Brain Res 465:293-301.

Chang JY, Martin DP, Johnson Jr EM (1990) Interferon suppresses sympathetic neuronal cell death caused by nerve growth factor deprivation. J Neurochem 55:436-445.

Chun LL, Patterson PH (1977) Role of nerve growth factor in the development of rat sympathetic neurons in vitro. I. Survival, growth, and differentiation of catecholamine production. J Cell Biol 75:694-704.

Corbin JG, Kelly D, Rath EM, Baerwald KD, Suzuki K, Popko B (1996) Targeted CNS expression of interferon-gamma in transgenic mice leads to hypomyelination, reactive gliosis, and abnormal cerebellar development. Mol Cell Neurosci 7:354-370.

Curtis R, Scherer SS, Somogyi R, Adryan KM, Ip NY, Zhu Y, Lindsay RM, DiStefano PS (1994) Retrograde axonal transport of LIF is increased by peripheral nerve injury: correlation with increased LIF expression in distal nerve. Neuron 12:191-204.

Ensoli F, Fiorelli V, Muratori DS, De Cristofaro M, Vincenzi L, Topino S, Novi A, Luzi G, Sirianni MC (1999) Immune-derived cytokines in the nervous system: epigenetic instructive signals or neuropathogenic mediators? Crit Rev Immunol 19:97-116.

Erkman L, Wuarin L, Cadelli D, Kato AC (1989) Interferon induces astrocyte maturation causing an increase in cholinergic properties of cultured human spinal cord cells. Dev Biol 132:375-388.

Everall IP, Heaton RK, Marcotte TD, Ellis RJ, McCutchan JA, Atkinson JH, Grant I, Mallory M, Masliah E (1999) Cortical synaptic density is reduced in mild to moderate human immunodeficiency virus neurocognitive disorder. HNRC group. HIV neurobehavioral research center. Brain Pathol 9:209-217.

Fabry Z, Raine CS, Hart MN (1994) Nervous tissue as an immune compartment: the dialect of the immune response in the CNS. Immunol Today 15:218-224.

Fan J, Bass HZ, Fahey JL (1993) Elevated IFN-gamma and decreased IL-2 gene expression are associated with HIV infection. J Immunol 151:5031-5040.

Farrar MA, Schreiber RD (1993) The molecular cell biology of interferon- $\gamma$ and its receptor. Annu Rev Immunol 11:571-611.

Fletcher TL, Cameron P, De Camilli P, Banker G (1991) The distribution of synapsin I and synaptophysin in hippocampal neurons developing in culture. J Neurosci 11:1617-1626.

Fletcher TL, De Camilli P, Banker G (1994) Synaptogenesis in hippocampal cultures: evidence indicating that axons and dendrites become competent to form synapses at different stages of neuronal development. J Neurosci 14:6695-6706.

Flood DG, Coleman PD (1990) Hippocampal plasticity in normal aging and decreased plasticity in Alzheimer's disease. Prog Brain Res 83:435-443.

Fuchs D, Moller AA, Reibnegger G, Werner ER, Werner-Felmayer G, Dierich MP, Wachter H (1991) Increased endogenous interferongamma and neopterin correlate with increased degradation of tryptophan in human immunodeficiency virus type 1 infection. Immunol Lett 28:207-211.

Ghosh AK, Yuan W, Mori Y, Chen SJ, Varga J (2001) Antagonistic regulation of type I collagen gene expression by interferon-gamma and transforming growth factor- $\beta$. Integration at the level of p300/CBP transcriptional coactivators. J Biol Chem 276:11041-11048.

Gil MP, Bohn E, O'Guin AK, Ramana CV, Levine B, Stark GR, Virgin HW, Schreiber RD (2001) Biologic consequences of STAT1independent IFN signaling. Proc Natl Acad Sci USA 98:6680-6685.

Goslin K, Asmussen H, Banker G (1998) Rat hippocampal neurons in low-density culture. In: Culturing nerve cells (Banker G, Goslin 2nd K, eds), pp 339-370. Cambridge, MA: MIT.

Guo X, Chandrasekaran V, Lein P, Kaplan PL, Higgins D (1999) Leukemia inhibitory factor and ciliary neurotrophic factor cause dendritic retraction in cultured rat sympathetic neurons. J Neurosci 19:2113-2121.

Guo X, Lin Y, Horbinski C, Drahushuk KM, Kim IJ, Kaplan PL, Lein P, Wang T, Higgins D (2001) Dendritic growth induced by BMP-7 requires Smad1 and proteasome activity. J Neurobiol 48:120-130.

Hallam DM, Capps NL, Travelstead AL, Brewer GJ, Maroun LE (2000) Evidence for an interferon-related inflammatory reaction in the trisomy 16 mouse brain leading to caspase-1-mediated neuronal apoptosis. J Neuroimmunol 110:66-75.

Hendry IA (1977) The effect of the retrograde axonal transport of nerve growth factor on the morphology of adrenergic neurones. Brain Res 134:213-223.

Hendry IA, Campbell J (1976) Morphometric analysis of rat superior cervical ganglion after axotomy and nerve growth factor treatment. J Neurocytol 5:351-360.

Higgins D, Iacovitti L, Joh TH, Burton H (1981) The immunocytochemical localization of tyrosine hydroxylase within rat sympathetic neurons that release acetylcholine in culture. J Neurosci 1:126-131.

Higgins D, Lein PJ, Osterhout DJ, Johnson MI (1991) Tissue culture of mammalian autonomic neurons. In: Culturing nerve cells (Banker G, Goslin 1st K, eds), pp177-205. Cambridge, MA: MIT.

Janknecht R, Wells NJ, Hunter T (1998) TGF- $\beta$-stimulated cooperation of Smad proteins with the coactivators $\mathrm{CBP} / \mathrm{p} 300$. Genes Dev 12:2114-2119.

Jonakait GM, Wei R, Sheng ZL, Hart RP, Ni L (1994) Interferongamma promotes cholinergic differentiation of embryonic septal nuclei and adjacent basal forebrain. Neuron 12:1149-1159.

Kawabata M, Imamura T, Inoue H, Hanai J, Nishihara A, Hanyu A, Takase M, Ishidou Y, Udagawa Y, Oeda E, Goto D, Yagi K, Kato M, Miyazono K (1999) Intracellular signaling of the TGF- $\beta$ superfamily by Smad proteins. Ann NY Acad Sci 886:73-82.

Kiefer R, Haas CA, Kreutzberg GW (1991) Gamma interferon-like immunoreactive material in rat neurons: evidence against a close relationship to gamma interferon. Neuroscience 45:551-560.

Korsching S (1993) The neurotrophic factor concept: a reexamination. J Neurosci 13:2739-2748.

Kristensson K, Aldskogius M, Peng ZC, Olsson T, Aldskogius H, Bentivoglio M (1994) Co-induction of neuronal interferon-gamma and nitric oxide synthase in rat motor neurons after axotomy: a role in nerve repair or death? J Neurocytol 23:453-459.

Kudo T, Takeda M, Tanimukai S, Nishimura T (1993) Neuropathologic changes in the gerbil brain after chronic hypoperfusion. Stroke 24:259-264.

LaFerla FM, Sugarman MC, Lane TE, Leissring MA (2000) Regional hypomyelination and dysplasia in transgenic mice with astrocytedirected expression of interferon- $\gamma$. J Mol Neurosci 15:45-59.

Lau LT, Yu AC (2001) Astrocytes produce and release interleukin-1, 
interleukin-6, tumor necrosis factor alpha, and interferon-gamma following traumatic and metabolic injury. J Neurotrauma 18:351-359.

Lebon P, Boutin B, Dulac O, Ponsot G, Arthuis M (1988) Interferongamma in acute and subacute encephalitis. Br Med J 296:9-11.

Lein P, Johnason M, Guo X, Rueger D, Higgins D (1995) Osteogenic protein-1 induces dendritic growth in rat sympathetic neurons. Neuron 15:597-605.

Li HL, Kostulas N, Huang YM, Xiao BG, van der Meide P, Kostulas V, Giedraitas V, Link H (2001) IL-17 and IFN-gamma mRNA expression is increased in the brain and systemically after permanent middle cerebral artery occlusion in the rat. J Neuroimmunol 116:5-14.

Li Q, Eiden LE, Cavert W, Reinhart TA, Rausch DM, Murry EA, Weihe E, Haase AT (1999) Increased expression of nitric oxide synthase and dendritic injury in simian immunodeficiency virus encephalitis. J Hum Virol 2:139-145.

Masliah E, Heaton RK, Marcotte TD, Ellis RJ, Wiley CA, Mallory M, Achim CL, McCutchan JA, Nelson JA, Atkinson JH, Grant I (1997) Dendritic injury is a pathological substrate for human immunodeficiency virus-related cognitive disorders. HN RC group. The HIV neurobehavioral research center. Ann Neurol 42:963-972.

Matteoli M, Takei K, Perin MS, Sudhof TC, De Camilli P (1992) Exoendocytotic recycling of synaptic vesicles in developing processes of cultured hippocampal neurons. J Cell Biol 117:849-861.

Merrill JE, Ignarro LJ, Sherman MP, Melinek J, Lane TE (1993) Microglial cell cytotoxicity of oligodendrocytes is mediated through nitric oxide. J Immunol 15:2132-2141.

Montgomery MM, Dean AF, Taffs F, Stott EJ, Lantos PL, Luthert PJ (1999) Progressive dendritic pathology in cynomolgus macaques infected with simian immunodeficiency virus. Neuropathol Appl Neurobiol 25:11-19.

Morikawa Y, Tohya K, Tamura S, Ichihara M, Miyajima A, Senba E (2000) Expression of interleukin-6 receptor, leukemia inhibitory factor receptor, and glycoprotein 130 in the murine cerebellum and neuropathological effect of leukemia inhibitory factor on cerebellar Purkinje cells. Neuroscience 100:841-848.

Nakajima K, Yamanaka Y, Nakae K, Kojima H, Ichiba M, Kiuchi N, Kitaoka T, Fukada T, Hibi M, Hirano T (1996) A central role for STAT3 in IL-6-induced regulation of growth and differentiation in M1 leukemia cells. EMBO J 15:3651-3658.

O'Lague PH, Obata K, Claude P, Furshpan EJ, Potter DD (1974) Evidence for cholinergic synapses between dissociated rat sympathetic neurons in cell culture. Proc Natl Acad Sci USA 71:3602-3606.

Oppenheim RW (1991) Cell death during development of the nervous system. Annu Rev Neurosci 14:453-501.

Osterhout DJ, Frazier WA, Higgins D (1992) Thrombospondin promotes process outgrowth in neurons from the peripheral and central nervous systems. Dev Biol 150:256-265.

Panitch HS (1992) Interferons in multiple sclerosis. Drugs 44:946-962.

Panitch HS, Hirsch RL, Schindler J, Johnson KP (1987) Treatment of multiple sclerosis with gamma interferon: exacerbations associated with activation of the immune system. Neurology 37:1097-1102.

Park JS, Bateman MC, Goldberg MP (1996) Rapid alterations in dendrite morphology during sublethal hypoxia or glutamate receptor activation. Neurobiol Dis 3:215-227.

Patt S, Gertz HJ, Gerhard L, Cervos-Navarro J (1991) Pathological changes in dendrites of substantia nigra neurons in Parkinson's disease: a Golgi study. Histol Histopathol 6:373-380.

Peterson JW, Bo L, Mork S, Chang A, Trapp BD (2001) Transected neurites, apoptotic neurons, and reduced inflammation in cortical multiple sclerosis lesions. Ann Neurol 50:389-400.

Popko B, Corbin JG, Baerwald KD, Dupree J, Garcia AM (1997) The effects of interferon- $\gamma$ on the central nervous system. Mol Neurobiol 14:19-35.

Purves D (1975) Functional and structural changes in mammalian sympathetic neurons following interruption of their axons. J Physiol (Lond) $252: 429-463$.
Purves D (1988) Body and brain: a trophic theory of neural connections. Cambridge, MA: Harvard UP.

Pyle JL, Kavalali ET, Choi S, Tsien RW (1999) Visualization of synaptic activity in hippocampal slices with FM1-43 enabled by fluorescence quenching. Neuron 24:803-808.

Ramana CV, Gil MP, Han Y, Ransohoff RM, Schreiber RD, Stark GR (2000) STAT1-independent regulation of gene expression in response to IFN-gamma. Proc Natl Acad Sci USA 98:6674-6699.

Rao SM, Leo GJ, Bernardin L, Unverzagt F (1991) Cognitive dysfunction in multiple sclerosis. I. Frequency, patterns, and prediction. Neurology 41:685-691.

Rockstroh JK, Kreuzer KA, Sauerbruch T, Spengler U (1998) Protein levels of interleukin-12 p70 holomer, its p40 chain, and interferongamma during advancing HIV infection. J Infect 37:282-286.

Ron MA, Callanan MM, Warrington EK (1991) Cognitive abnormalities in multiple sclerosis: a psychometric and MRI study. Psychol Med 21:59-68.

Rothwell NJ, Hopkins SJ (1995) Cytokines and the nervous system. II. Actions and mechanisms of action. Trends Neurosci 18:130-136.

Schindler C (1999) Cytokines and JAK-STAT signaling. Exp Cell Res 253:7-14.

Senger DL, Campenot RB (1997) Rapid retrograde tyrosine phosphorylation of trkA and other proteins in rat sympathetic neurons in compartmented cultures. J Cell Biol 138:411-421.

Smith DS, Skene JH (1997) A transcription-dependent switch controls competence of adult neurons for distinct modes of axon growth. J Neurosci 17:646-658.

Stephens JM, Lumpkin SJ, Fishman JB (1998) Activation of signal transducers and activators of transcription 1 and 3 by leukemia inhibitory factor, oncostatin-M, and interferon-gamma in adipocytes. J Biol Chem 273:31408-31416.

Sumner BE, Watson WE (1971) Retraction and expansion of the dendritic tree of motor neurones of adult rats induced in vivo. Nature 233:273-275

Sun Y, Landis SC, Zigmond RE (1996) Signals triggering the induction of leukemia inhibitory factor in sympathetic superior cervical ganglia and their nerve trunks after axonal injury. Mol Cell Neurosci 7:152-163.

Swanson LW, Kohler C, Bjorklund A (1987) The limbic region. I. The septohippocampal system. In: Handbook of chemical neuroanatomy, Vol 5 (Bjorklund A, Hokfelt T, Swanson LW, eds), pp 125-277. New York: Elsevier.

Takashima S, Ieshima A, Nakamura H, Becker LE (1989) Dendrites, dementia, and the Down syndrome. Brain Dev 11:131-133.

Taupin V, Toulmond S, Serrano A, Benavides J, Zavala F (1993) Increase in IL-6, IL-1, and TNF levels in rat brain following traumatic lesion. Influence of pre- and post-traumatic treatment with Ro5 4864, a peripheral-type ( $\mathrm{p}$ site) benzodiazepine ligand. J Neuroimmunol 42:177-185.

Torre D, Broggini M, Zeroli C, Agrifoglio L, Botta V, Casalone R, Ferrario G (1995) Serum levels of gamma interferon in patients with Down's syndrome. Infection 23:66-67.

Traugott U, Lebon P (1988) Interferon-gamma and Ia antigen are present on astrocytes in active chronic multiple sclerosis lesions. J Neurol Sci 84:257-264.

Vikman KS, Owe-Larsson B, Brask J, Kreistensson KS, Hill RH (2001) Interferon- $\gamma$-induced changes in synaptic activity and AMPA receptor clustering in hippocampal cultures. Brain Res 896:18-29.

Weller M, Stevens A, Sommer N, Melms A, Dichgans J, Wietholter H (1991) Comparative analysis of cytokine patterns in immunological infectious, and oncological neurological disorders. J Neurol Sci 104:215-221.

Yawo H (1987) Changes in the dendritic geometry of mouse superior cervical ganglion cells following postganglionic axotomy. J Neurosci 7:3703-3711. 